\title{
Chemical Profile and Antioxidant Properties of Mundulea sericea
}

\author{
Mahendra Shivshankar Khyade ${ }^{* 1}$, Mohan Baban Waman ${ }^{2}$
}

\section{Mahendra Shivshankar Khya- de $^{* 1}$, Mohan Baban Waman ${ }^{2}$ 'Department of Botany, S.N. Arts, D.J.M. Commerce and B.N.S. Science Col- lege, Sangamner- 422605.Affiliated to Savitribai Phule Pune University, Pune (MS), INDIA. \\ ${ }^{2}$ Dr. D.Y. Patil Arts, Commerce and Sci- ence College, Pune- 411044, INDIA.}

\section{Correspondence}

\section{Dr. Mahendra Shivshankar Khyade}

Department of Botany, S. N, Arts, D. J. M. Commerce and B.N. S.Science College, Sangamner- 422605. Affiliated to Savitribai Phule Pune University,Pune (MS), INDIA.

Mob.No: 9921428085

Tel. /fax: +912425225893

E-mail: maheshkhyade@gmail.com

\section{History}

- Submission Date: 27-10-2016

- Review completed: 08-11-2016;

- Accepted Date: 27-12-2016.

DOI : 10.5530/pj.2017.2.36

Article Available online

http://www.phcogj.com/v9/i2

\section{Copyright}

(C) 2017 Phcog.Net. This is an openaccess article distributed under the terms of the Creative Commons Attribution 4.0 International license.

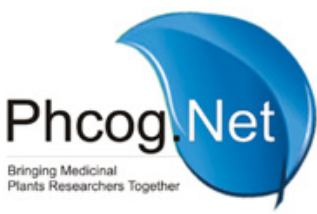

\begin{abstract}
Objectives: To evaluate the phytochemical composition and the antioxidant activity of aqueous-methanolic (20:80) leaves extract of Mundulea sericea Willd. Methods: The extract of leaves was tested for antioxidant activity using various in vitro models viz., 2,2-diphenyl-1-picrylhydrazyl (DPPH), nitric oxide, ABTS, ferric reducing antioxidant power (FRAP), total antioxidant activity and reducing power. The phytochemical composition (GC-MS and HPLC) along with total phenolic and flavonoid content of the extract at different concentrations were also determined. Results: Total phenolic and flavonoid contents were found to be equivalents to $107.86 \pm 0.53 \mu \mathrm{g}$ of gallic acid and $44.53 \pm 0.156 \mu \mathrm{g}$ of rutin $/ \mathrm{mg}$ of dried hydro-methanolic methanolic extract, respectively. Among various antioxidant assays performed, maximum inhibition was observed for ABTS (IC $\left.C_{50} 13.26 \pm 0.396 \mu \mathrm{g}\right)$ followed by DPPH $\left(\mathrm{IC}_{50} 79.83 \pm 0.306 \mu \mathrm{g}\right)$ and $\mathrm{NO}\left(\mathrm{IC}_{50} 6.35 \pm 0.23 \mu \mathrm{g} / \mathrm{mL}\right)$ assay. The GC-MS analysis revealed over 38 compounds; the prevailing compounds were Sec- Butyl ethyl sulfoxide and Di-methyl sulfoxonium formyl methylide. The RP-HPLC analysis further confirmed the presence of rutin, cinnamic acid and salicylic acid. Conclusion: The results of the present study demonstrated that Mundulea sericea leaves possess high phenolic with flavonoid contents and also revealed potential antioxidant activity so these leaves could be used as a viable source of natural antioxidants for industrial and pharmaceutical preparations.
\end{abstract}

Key words: Mundulea sericea, Leaf extract, Antioxidant, GC-MS, RP-HPLC, Phenolics, Flavonoids

\section{INTRODUCTION}

Now a days, antioxidants derived from plants have been gaining more attention due to their therapeutic implications and fewer side effects. ${ }^{1}$ Moreover, the published research literature reveals that the large number of plants including aromatic, spicy and medicinal plants contains important secondary metabolites that exhibit antioxidant properties. ${ }^{2}$ In addition, several experimental studies conducted on some of these plants, viz, rosemary, sage, oregano, resulted in the development of natural antioxidant formulations for food, cosmetic and other applications. ${ }^{3,4}$ However, scientific data on antioxidant properties of plants that are less widely used in food and medicine is still rather scarce. Therefore, the screening of plants having such properties remains an interesting and useful task, particularly for finding new sources of natural antioxidants. $^{5}$

Mundulea sericea (Willd.) A.Chev. is a small tree belonging to the family fabaceae, distributed in dry forests and rocky hills of West and South India. The plant is reported to have an insecticidal properties and also reported in stupefying fishes. ${ }^{6,7}$ In Africa, bark, leaves, seeds and roots of this plant have been used as fish poison, insecticide and as an aphrodisiac. ${ }^{8,9}$ There are many reports on bioactivity of M. sericea, such as insecticidal, ${ }^{9-11}$ anti-mycobacterial, ${ }^{12}$ antimicrobial ${ }^{13}$ and analgesic activity ${ }^{7}$ is also reported. However there is little research report on the antioxidant potential and chemical profiling of leaves of this plant. Hence, the present study is aims to quantify the total phenolic and total flavonoid contents of the aqueous methanolic extract of the $M$. sericea leaves and to investigate the antioxidant capacity using six different methods. Furthermore, the extract was further analyzed by spectroscopic and chromatographic techniques (FTIR, GC-MS and RP-HPLC) for the characterization of chemical composition.

\section{MATERIALS AND METHODS}

\section{Sample collection and extraction}

The leaves of M. sericea were harvested from Baleshwar hills of Sangamner Tehsil located in the northwest region of Ahmednagar district (MS), India. The collected plant specimen was authenticated at the Department of Botany, Sangamner College, Sangamner, by using Floras. ${ }^{14,15}$ The plant material was washed with tap water to remove the dust particles and shade dried at room temperature. It is thereafter ground into fine powder with an electric grinder. The dried powdered material (100 g) was extracted with aqueous-methanol (20:80) by adopting cold the extraction method. ${ }^{16,17}$ The mixture was kept for 48 $\mathrm{h}$ with frequent shaking at room temperature. Afterward, the extract was filtered through Whatman No. 41 filter paper and dried by rotavapor at $40^{\circ} \mathrm{C}$. The extraction procedure was repeated thrice. The extract thus obtained was preserved in the refrigerator for further use.

\section{Phytochemical analysis Qualitative phytochemical analysis}

The aqueous-methanolic extract of the leaves was subjected to detection of various phytoconstituents 
such as alkaloids, cardiac glycosides, caumarins, flavonoids, phenolic compounds, reducing sugar, saponins, steroids, tannins and terpenoids by reported methods. ${ }^{16}$

\section{Quantification of total phenolics}

The total phenol (TPC) content of the extract was determined by using described method. ${ }^{18}$ Briefly, the extract $(0.2 \mathrm{ml}$ of $1 \mathrm{mg} / \mathrm{ml})$ was mixed with $2.5 \mathrm{ml}$ of distilled water. After $0.5 \mathrm{ml}$ of the Folin-Ciocalteu reagent and $1.0 \mathrm{ml}$ of $\mathrm{Na}_{2} \mathrm{CO}_{3}$ reagent were added to the mixture, and incubated at room temperature for $30 \mathrm{~min}$. The absorbance of the mixture was measured spectrophotometrically (Systronic UV-VIS India) at $765 \mathrm{~nm}$. The total phenol content was expressed in microgram gallic acid equivalents per milligram of extract ( $\mu \mathrm{g}$ GAE/mg DW) through the calibration curve with gallic acid. Triplicate measurements were taken and data were presented as mean \pm standard deviation $(\mathrm{Mean} \pm \mathrm{SD})$.

\section{Quantification of total flavonoids}

The total flavonoid (TFC) content of the extract was determined by using described methods. ${ }^{19,20}$ In brief; $0.1 \mathrm{ml}$ of sample solution $(1 \mathrm{mg} / \mathrm{ml})$ was mixed with $2 \mathrm{ml}$ of distilled water and subsequently with $0.15 \mathrm{ml}$ of $\mathrm{NaNO}_{2}(5 \%)$ After $6 \mathrm{~min}$ of incubation, $0.15 \mathrm{ml}$ of $10 \% \mathrm{AlCl}_{3}$ solution was added and allowed to stand for $6 \mathrm{~min}$, it was followed by addition of $2 \mathrm{ml}$ of Noah (4\%) to the mixture. The final volume was adjusted to $5 \mathrm{ml}$ with distilled water and thoroughly mixed. The absorbance of the mixture was determined at $510 \mathrm{~nm}$. Total flavonoid content was expressed as $\mu \mathrm{g}$ rutin/mg dry weight, through the calibration curve of rutin (10-100 $\mu \mathrm{g} / \mathrm{ml}$ ). All samples were analyzed in triplicates and data were presented as mean \pm standard deviation (Mean $\pm \mathrm{SD})$.

\section{Antioxidant activity assays $D P P H$ radical scavenging assay}

The DPPH (2,2 diphenyl-1-picrylhydrazyl) free radical scavenging capacity of extract was measured by using standard protocol ${ }^{21}$ with slight modifications. Briefly, the reaction mixture contained $300 \mu \mathrm{l}$ of extract of varying concentrations $(10-300 \mu \mathrm{g} / \mathrm{ml})$ and $2 \mathrm{ml}$ of DPPH solution. After $10 \mathrm{~min}$, the change in absorbance was recorded at $517 \mathrm{~nm}$ in a spectrophotometer against a blank. L-ascorbic acid was used as a positive control. The DPPH radical scavenging capacities were expressed as L-ascorbic acid equivalent antioxidant capacity in $\mathrm{mmol} \mathrm{g}^{-1}$ of extract. The $\%$ DPPH scavenging activity was calculated by the equation:

$\%$ DPPH scavenging activity $=A_{\text {control }}-A_{\text {sample }} / A_{\text {control }} \times 100$

Where $A_{\text {control }}$ is the absorbance of the control (DPPH + methanol) and $A_{\text {sample }}$ is the absorbance of the sample (DPPH + methanol + sample). The extract concentration providing $50 \%$ inhibition $\left(\mathrm{IC}_{50}\right)$ was calculated from the graph of scavenging effect percentage against extract concentration in the solution.

\section{2, 2-Azino-bis (3-ethylbenzthiazoline-6-sulphonic acid) radical-scavenging assay (ABTS)}

ABTS radical scavenging activity was determined by using standard described method. ${ }^{22}$ The ABTS radical cations are produced when ABTS $(7 \mathrm{mM})$ reacts with potassium persulfate $(2.45 \mathrm{mM})$ when incubated at room temperature in the dark for $16 \mathrm{hrs}$. The solution thus obtained was further diluted with phosphate buffer saline (PBS) to give an absorbance of 1.000. Different concentrations of the test samples in $50 \mu \mathrm{l}$ were added to $950 \mu \mathrm{l}$ of ABTS working solution to give a final volume of $1 \mathrm{ml}$. The absorbance was recorded immediately at $734 \mathrm{~nm}$. Ascorbic acid was used as a reference standard and inhibiting concentrations of extracts were tested at $10,20,40,60,80$ and $100 \mu \mathrm{g} / \mathrm{ml}$. All determinations were performed in triplicate. Reference standard (Ascorbic acid) was also tested with similar concentrations and percent inhibition was calculated by following equation:
$\%$ inhibition $=\left(\left[\mathrm{A}_{\text {blank }}-\mathrm{A}_{\text {sample }}\right] / \mathrm{A}_{\text {blank }}\right) \times 100$.

Where $A_{\text {blank }}$ is the absorbance of ABTS radical + methanol used as control; $\mathrm{A}_{\text {sample }}$ is the absorbance of ABTS radical + sample extract/standard. Also the results were given as the $\mathrm{IC}_{50}$, which was calculated from the graph of the $\mathrm{ABTS}^{\circ+}$ scavenging effect percentage against the sample concentration

\section{Nitric oxide radical scavenging assay}

The nitric oxide scavenging activity of extracts on nitric oxide radical was measured according to the method. ${ }^{23}$ Sodium nitroprusside $(1 \mathrm{ml}$, $5 \mathrm{mM})$ in PBS $(0.1 \mathrm{M}, 7.4 \mathrm{pH})$ was mixed with $3 \mathrm{ml}$ of different concentration of the extract and incubated at $25^{\circ} \mathrm{C}$ for $150 \mathrm{~min}$. Afterward, $0.5 \mathrm{ml}$ of the this sample was mixed with $0.5 \mathrm{ml}$ of Griess reagent $(1 \%$ sulphanilamide, $2 \% \mathrm{H}_{3} \mathrm{PO}_{4}$ and $0.1 \%$ napthyl ethylene diamine dihydrochloride) and absorbance was measured at $546 \mathrm{~nm}$. Reference standard (L-ascorbic acid) was also tested with similar concentrations and percent inhibition was calculated by following equation:

$\%$ inhibition $=\left(\left[\mathrm{A}_{\text {blank }}-\mathrm{A}_{\text {sample }}\right] / \mathrm{A}_{\text {blank }}\right) \times 100$.

The $\mathrm{IC}_{50}$ values was calculated from the graph of scavenging effect percentage against extract concentration in the solution.

\section{Reducing power assay}

The reducing power of extracts was evaluated according to the method described by ${ }^{21}$ with slight modification. Briefly, different amounts of extracts $(100-700 \mu \mathrm{g} / \mathrm{ml})$ were incubated with $2.5 \mathrm{ml}$ of PBS $(0.2 \mathrm{M}, \mathrm{pH}$ 6.6) and $2.5 \mathrm{ml}$ of $1 \%$ potassium ferricyanide at $50^{\circ} \mathrm{C}$ for $20 \mathrm{~min}$. The reaction was terminated by adding $2.5 \mathrm{ml}$ of $10 \%$ TCA solution and the mixture was centrifuged at $3000 \mathrm{rpm}$ for $10 \mathrm{~min}$. The supernatant $(1.0$ $\mathrm{ml}$ ) was mixed with $2.5 \mathrm{ml}$ of distilled water and $1.0 \mathrm{ml}$ of $0.1 \%$ ferric chloride $\left(\mathrm{FeCl}_{3}\right)$ solution and absorbance was measured at $700 \mathrm{~nm}$ after incubation at room temperature for $10 \mathrm{~min}$. Quercetin and butylated hydroxy toluene $(5-50 \mu \mathrm{g} / \mathrm{ml})$ were used as positive control and experiment was performed in triplicate.

\section{Ferric reducing activity}

The FRAP (Ferric reducing antioxidant power) assay was conducted according to standard protocol. ${ }^{24}$ The method is based on the reduction of a ferric 2, 4, 6-tripyridyl-s-triazine complex ( $\mathrm{Fe}^{3+}$-TPTZ) by antioxidants to the ferrous form ( $\mathrm{Fe}^{2+}$-TPTZ). FRAP reagent was prepared freshly by mixing $2.5 \mathrm{~mL}$ of TPTZ solution $(10 \mathrm{mM}$ in $40 \mathrm{mM} \mathrm{HCl})$ and $\mathrm{FeCl}_{3}(20$ $\mathrm{mM})$ in $25 \mathrm{~mL}$ of acetate buffer $(300 \mathrm{mM}$ and $\mathrm{pH}$ 3.6). The light blue $\mathrm{Fe}^{3+}$-TPTZ reagent changes to dark blue after contact with an antioxidant, due to the formation of Fe2+-TPTZ. Absorbance was monitored at $593 \mathrm{~nm}$ for two different concentrations (100 and $200 \mu \mathrm{g} / \mathrm{mL}$ ) of extracts in FRAP reagent. All the results were based on three separate experiments and antioxidant capacity was expressed as $\mu \mathrm{M} \mathrm{FeSO}_{4} / \mathrm{mg}$ of dry extract. Quercetin and butylated hydroxy toluene were used as positive control.

\section{Total antioxidant capacity}

The aqueous extract $(0.4 \mathrm{ml}, 1 \mathrm{mg} / \mathrm{ml})$ was combined in test tube with 4 $\mathrm{ml}$ of the reagent solution $(0.6 \mathrm{M}$ sulphuric acid, $28 \mathrm{mM}$ sodium phosphate and $4 \mathrm{mM}$ ammonium molybdate). The tubes were capped and incubated at $95^{\circ} \mathrm{C}$ for $90 \mathrm{~min}$. After cooling to room temperature, the absorbance was measured at $695 \mathrm{~nm}$ against blank. The antioxidant activity was expressed as the number of equivalents of L-ascorbic acid. ${ }^{25,26}$

\section{FT-IR analysis for phytochemical screening}

FTIR (Fourier Transform Infrared Spectroscopy) analysis of aqueous methanol extract was performed using Chemito 410 Spectrophotometer to confirm class of phytochemicals. The dried extract was ground into a 
fine powder using an agate mortar along with a standard $\mathrm{KBr}$ tablet (1:8) and examined with scan time $(10 \mathrm{~min})$ at a resolution of $4 \mathrm{~cm}^{-1}$ ranging from $4000-400 \mathrm{~cm}^{-1} .{ }^{27}$ The room was kept at a controlled ambient temperature $\left(25^{\circ} \mathrm{C}\right)$ and relative humidity $(30 \%)$.

\section{GC-MS analysis}

The extract, was dissolved in HPLC grade methanol and analyzed by gas chromatography (GC) coupled with a mass spectrometer (MS) using a THERMO GC (TRACE 1300) with a fused silica capillary column, PE-5 $(50 \mathrm{~m} \times 0.32 \mathrm{~mm}$, film thickness $0.25 \mu \mathrm{m})$ and a triple quadrapole Thermo MS (TSQ 8000) mass spectrometer. A sample of $5.0 \mu \mathrm{l}$ was injected in the split mode with split ratio 10:1. An electron ionization (EI) system, with electron energy of $70 \mathrm{eV}$ and emission current $200 \mu \mathrm{A}$ was used for GC-MS detection. Helium was used as a carrier gas at a flow rate of $1 \mathrm{ml} / \mathrm{min}$ and ionization temperature was kept at $200^{\circ} \mathrm{C}$. The GCMS was equipped with Dyna Max XR detection system having discrete dynode electron multiplier and electrometer. The mass scanning range was varied over 40-550 $\mathrm{Da}$ and for run time of $40 \mathrm{~min}$. The components of the extract were identified by their retention time and compared with mass spectrum data from the National Institute Standard and Technology (NIST) library available with the GC-MS system.

HPLC analysis

To identify phenolic components, HPLC analysis of the extract was carried out using Younglin's HPLC (Acme-9000) instrument (Kyounggi, Korea) equipped with UV detector. C18 column used was (Cosmosil RP $150 \mathrm{~mm} \times 4.6 \mathrm{~mm}$ i.d., $5 \mu \mathrm{m}$ particle size). The injection volume was 20 $\mu \mathrm{l}$. Acetonitrile: water $(60: 40)$ was the mobile phase and detection was carried out at wavelength $230 \mathrm{~nm}$. The isocratic flow was kept constant at $10 \mathrm{ml} / \mathrm{min}$. The phenolic compounds were identified by qualitatively and quantitatively comparing the peak areas on the chromatograms of samples with those of different known standards. Stock solutions of rutin, quercitin, gallic acid, vanillic acid, benzoic acid, cinnamic acid and salicylic acid were prepared in methanol $(1 \mathrm{mg} / 10 \mathrm{ml})$. The aqueousmetanolic extract of $M$. sericea were prepared at concentration of $10 \mathrm{mg} /$ $\mathrm{mL}$ in HPLC grade methanol. Both sample and standards were prepared fresh and used for analysis immediately.

\section{RESULTS AND DISCUSSION}

The preliminary phytochemical constituents revealed the presence of coumarins, flavonoids, phlobatannins, saponins, steroids, and tannins, while alkaloids, terpenoids and glycosides were not reported in the tests.

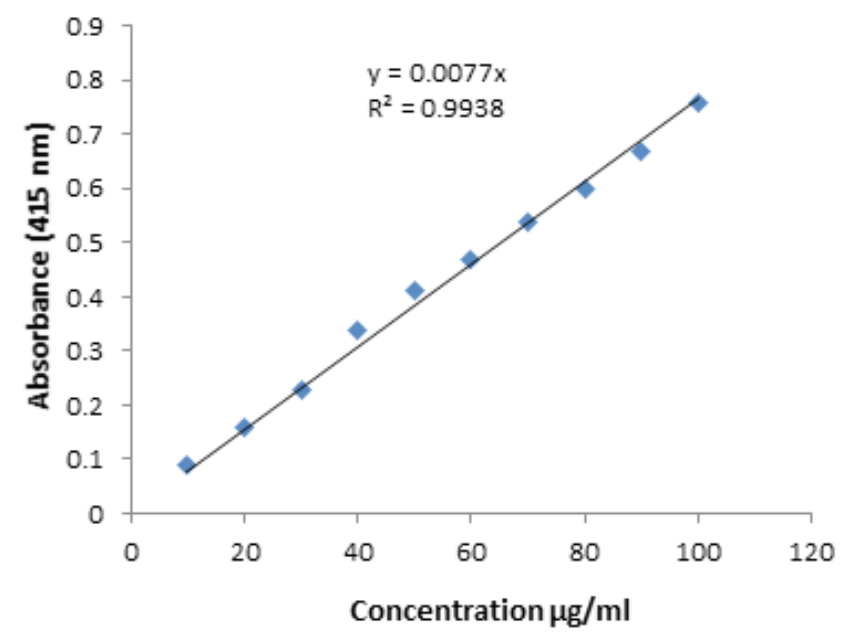

Figure 1: Standard curve of gallic acid for determination of total phenolic contents.
All these constituents are reported to exhibit strong antioxidant scavenging activity for the radicals involved in the lipid peroxidation. ${ }^{28,29} \mathrm{In}$ addition, these phytoconstituents play a vital role in the treatment of different diseases such as tannins possess anti-inflammatory and anticancer activity; ${ }^{30,31}$ flavonoids are known to be antioxidant, anti-inflammatory and anticancer agents; ${ }^{32}$ coumarins are also acts as an antioxidant and also reported to maintain blood pressure and inhibit lipid peroxidation ${ }^{33}$ and saponin are antimicrobial agent and maintain the blood cholesterol level. ${ }^{34}$

The phenolics and flavonoids are the widely distributed classes of chemical constituents among the plant kingdom. Both these compounds are reported to be efficient radical scavengers and metal chelator and gained much attention in the scientific world as a source of natural antioxidant. Besides, the published research literature demonstrated that the antioxidant activity of phenolic is mainly due to their redox properties, hydrogen donors and singlet oxygen quenchers and flavonoids with powerful antioxidant properties. ${ }^{35,36}$ TPC was calculated using the standard curve of gallic acid (standard curve equation: $\mathrm{Y}=0.021 \mathrm{x}, \mathrm{R}^{2}=0.992$ ) and TFC was calculated using the standard curve of rutin (standard curve equation: $\mathrm{Y}=0.007 \mathrm{x}, \mathrm{R}^{2}=0.993$ ) as shown in Figure 1 and 2 . In our study, the TPC and TFC contents were estimated to be equivalents to $107.86 \pm 0.053 \mu \mathrm{g}$ of gallic acid and $44.53 \pm 0.156 \mu \mathrm{g}$ of rutin/mg of dried aqueous-methanolic extract, respectively. However, like other plants, phenolic and flavonoid contents of the plants are influenced by environmental condition where it is growing. ${ }^{37}$

The FT-IR spectra of an aqueous-methanolic extract of leaves of M. sericea are shown in Figure 3. The FTIR analysis of the extract predominantly revealed the presence of alcohols, phenols, alkanes, alkynes, aldehydes, carboxylic acids, aromatics, nitro compounds unsaturated esters and amines in the extract. The absorption at $2921 \mathrm{~cm}^{-1}$ is due to the $\mathrm{C}-\mathrm{H}$ stretching which means that some alkane compounds are present in the extract. The band at $2360 \mathrm{~cm}^{-1}$ showed (C-N) nitrile stretch; band at $1731 \mathrm{~cm}^{-1}$ confirms the aldehyde or saturated aliphatic groups $(\mathrm{C}=\mathrm{O})$; the peak at 1267 and $1055 \mathrm{~cm}^{-1}$ indicated aromatic amine groups respectively $(\mathrm{C}-\mathrm{N})$. The strong band was observed at $1100 \mathrm{~cm}^{-1}$ was attributed to alcohols, carboxylic acids, esters and ether groups (C-O). The bands at $927 \mathrm{~cm}-1$ represent Phenol or tertiary alcohol, $\mathrm{OH}$ bend. The present FT-IR spectral analysis showed the presence of phytochemicals carrying hydrogen bonded -OH functional group. It is already reported that hydroxyl functionality is an integral part of most of the phenolics such as flavonoids and tannins. ${ }^{38}$ Moreover, recent studies also show that sev-

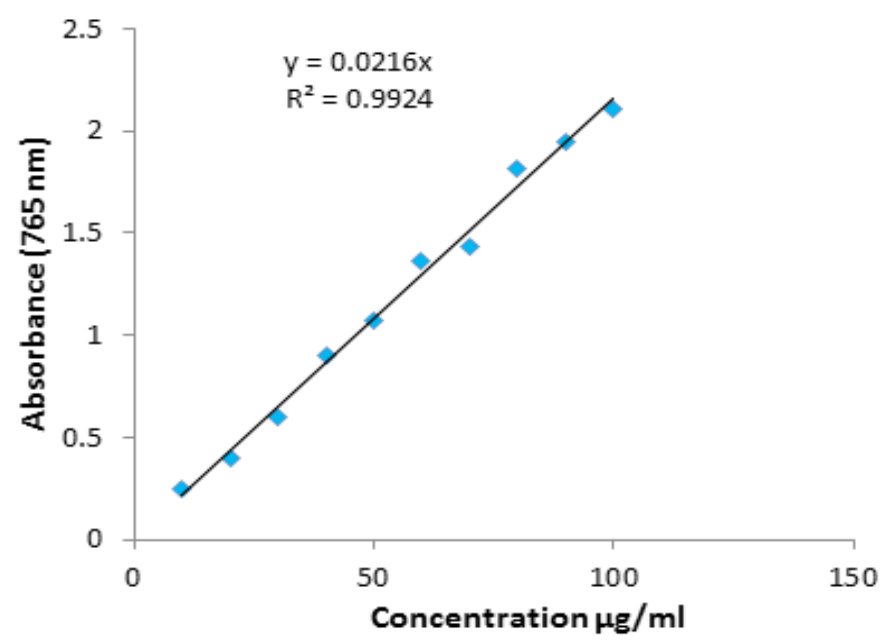

Figure 2: Standard curve of rutin for determination of total flavonoid contents. 
eral plant products, including polyphenolic substances (e.g., flavonoids and tannins) and various herbal extracts, show antioxidant ${ }^{39-42}$ and antiinflammatory activities. ${ }^{42}$ Our results revealed that the extract contains various bioactive functional groups, viz. alcoholic, ester, aldehydic etc., and hence it can confirm that the plant accumulated with diverse bioactive molecules.

Secondary metabolite screening of plant extracts by gas chromatography and mass spectrometry (GC-MS) renders the more sensitive detection of biological active compounds. Earlier researcher analyzed plant extracts using GC-MS ${ }^{43}$ were reported for the findings of various biological properties such as antimicrobial, ${ }^{44}$ anticancer, chemopreventive, anthelmintic and antiproliferative properties. ${ }^{45}$ Till date no reports exist on the GC-MS analysis of $M$. sericea. The bioactive compounds present in the aqueous methanolic extract of leaf of $M$. sericea were identified by GC-MS analysis (Figure 4). The identified compounds, their retention indices, percentage composition, chemical structure and activities are given in Table 1, there were 2 major peaks and a total of 38 components were observed. The major phytochemical constituents were Sec- Butyl ethyl sulfoxide $(80.57 \%)$ and Dimethylsulfoxonium formylmethylide (18.57\%). Among the other identified phytochemicals, cinnamic acid, hexadecanoic acid and 9,12,15-Octadecatrienoic acid showed antioxidant, hypocholesterolemic, antiinflammatory, anticancer and hepatoprotective, activities.

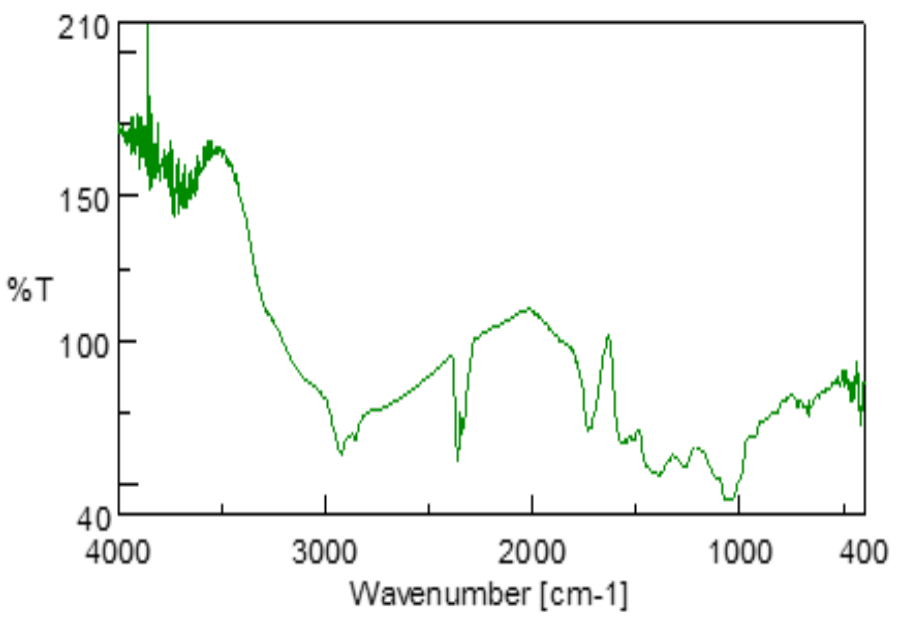

Figure 3: FT-IR spectrum of aqueous-methanolic leaf extract.

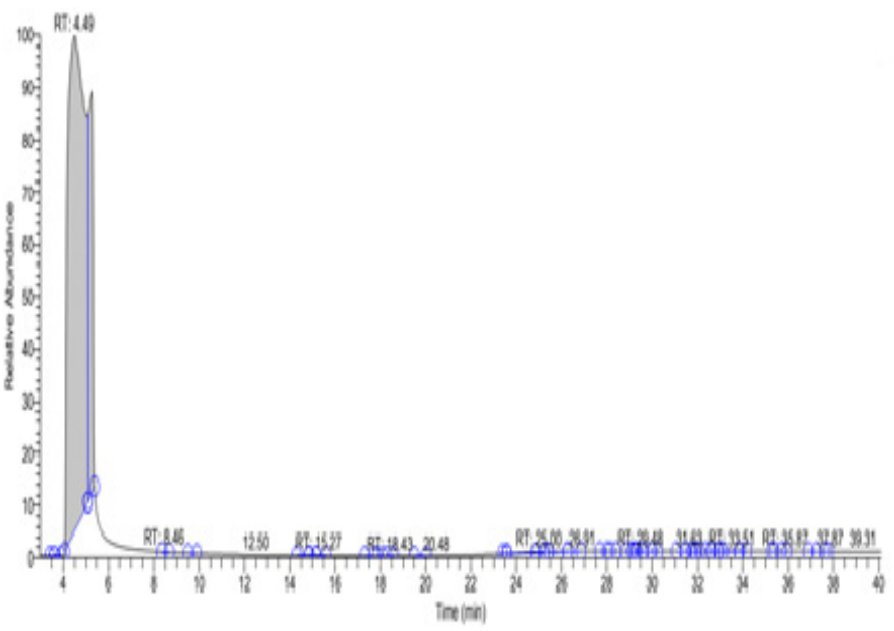

Figure 4: GC-MS Chromatogram of aqueous-methanolic leaf extract.
The HPLC fingerprint of aqueous-methanolic leaves extract of $M$. sericea revealed the 14 major and minor peaks that were detected at $230 \mathrm{~nm}$ (Figure 5). The peaks at retention time 2.30, 338 and 3.90 were identified as rutin, salicylic acid and benzoic acid respectively. The phenolic compounds were identified from the extract by matching their retention times against those of the standards. Rutin was found to have the highest concentration $(4.66 \mu \mathrm{g} / \mathrm{mg})$, followed by cinnamic acid $(0.84 \mu \mathrm{g} / \mathrm{mg})$ and salicylic acid $(2.65 \mu \mathrm{g} / \mathrm{mg})$. All these phenolics are known to have antioxidant properties. Present findings however, obtained in this work cannot be compared with those reported in earlier research literatures. Since it is first attempt on the preliminary identification and quantification of phenolics compounds in this plant, and secondly the retention times depend on factors such as solvent composition, extract matrix and environment where the plant is growing.

As per the earlier reports there is no single testing method, which is capable of providing a comprehensive picture of the antioxidant profile of a given sample, since plant extract contain different antioxidant components and most of the oxidation-antioxidation processes are complex. ${ }^{37}$ Accordingly, multiple methods are often collectively used to describe antioxidant activity of plant extracts. ${ }^{46}$ Herein, we have used six different in-vitro assay models for evaluation of the antioxidant activity.

The DPPH assay has been widely used to investigate the radical scavenging activity. DPPH, a radical itself with a purple color, changes into a

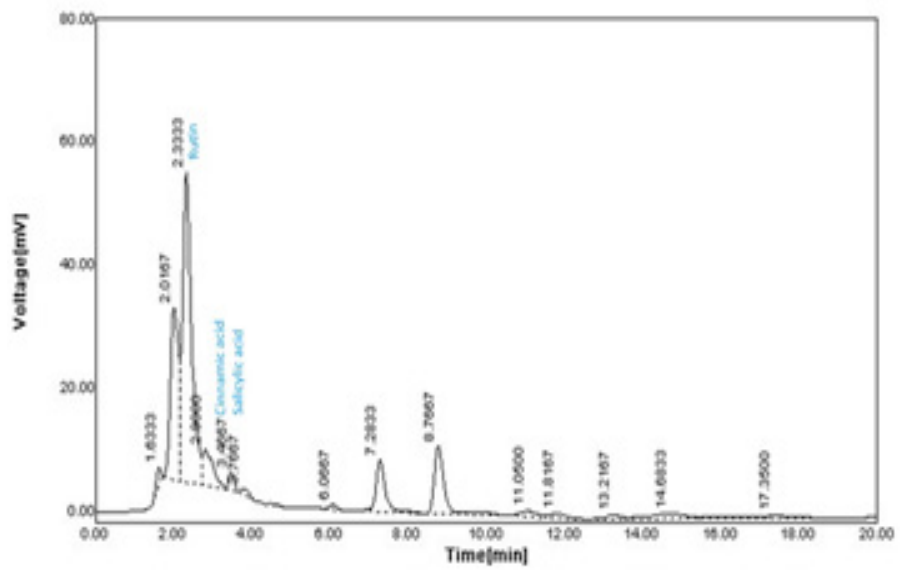

Figure 5: HPLC Chromatographic profile of aqueous-methanolic leaf extract.

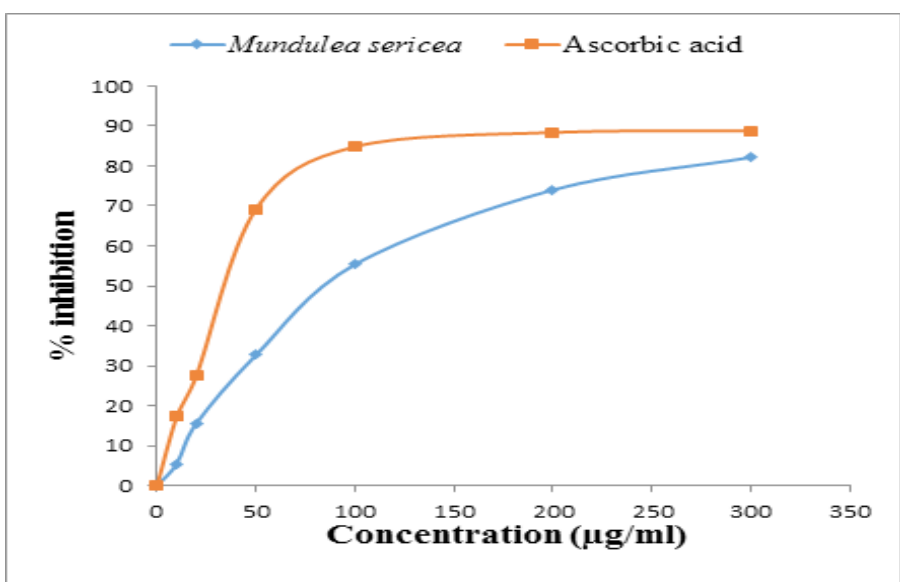

Figure 6: DPPH scavenging activity of aqueous-methanolic leaf extract of M. sericea 
Table 1: Compounds identified from the aqueous-methanolic leaves extract of M. sericea by GC-MS

\begin{tabular}{|c|c|c|c|c|}
\hline RT & Name of compound & Molecular Formula & $\begin{array}{c}\text { Molecular weight } \\
(\mathrm{g} / \mathrm{mol})\end{array}$ & $\%$ peak area \\
\hline 4.49 & Sec- Butyl ethyl sulfoxide & $\mathrm{C}_{6} \mathrm{H}_{14} \mathrm{~S}$ & 118.24 & 80.57 \\
\hline 3.48 & Ethyl isoallocholate & $\mathrm{C}_{26} \mathrm{H}_{44} \mathrm{O}_{5}$ & 436 & 00 \\
\hline 3.48 & Pterin-6-carboxylic acid & $\mathrm{C}_{7} \mathrm{H}_{5} \mathrm{~N}_{5} \mathrm{O}_{3}$ & 207.15 & 00 \\
\hline 3.48 & Cinnamic acid & $\mathrm{C}_{9} \mathrm{H}_{8} \mathrm{O}_{2}$ & 148.16 & 00 \\
\hline 3.70 & 10-Heptadecen-8-ynoic acid, methyl ester & $\mathrm{C}_{18} \mathrm{H}_{30} \mathrm{O}_{2}$ & 278.42 & 0.01 \\
\hline 3.70 & E-Paromomycin & $\mathrm{C}_{23} \mathrm{H}_{45} \mathrm{~N}_{5} \mathrm{O}_{14}$ & 615.62 & 0.01 \\
\hline 5.27 & Dimethylsulfoxoniumformylmethylide & $\mathrm{C}_{4} \mathrm{H}_{8} \mathrm{O}_{2} \mathrm{~S}$ & 120.17 & 18.78 \\
\hline 8.46 & (1-Bromo-ethanesulfinyl)- ethane & $\mathrm{C}_{4} \mathrm{H}_{9} \mathrm{BrOS}$ & 185.08 & 0.01 \\
\hline 14.54 & Diethyl Phthalate & $\mathrm{C}_{12} \mathrm{H}_{14} \mathrm{O}_{4}$ & 222.24 & 0.01 \\
\hline 14.54 & Phthalic acid, ethyl isoporpyl ester & $\mathrm{C}_{13} \mathrm{H}_{16} \mathrm{O}_{4}$ & 236.26 & 0.01 \\
\hline 15.02 & 8-epi-.gama.-eudesmol & $\mathrm{C}_{15} \mathrm{H}_{26} \mathrm{O}$ & 222.37 & 0.01 \\
\hline 15.02 & Agarospirol & $\mathrm{C}_{15} \mathrm{H}_{24} \mathrm{O}_{2}$ & 236.34 & 0.01 \\
\hline 15.27 & 2-Naphthalenemethanol & $\mathrm{C}_{11} \mathrm{H}_{10} \mathrm{O}$ & 158.19 & 0.02 \\
\hline 17.48 & Phthalic acid, hept-4-yl isobutyl ester & $\mathrm{C}_{19} \mathrm{H}_{28} \mathrm{O}_{4}$ & 320.42 & 0.01 \\
\hline 17.48 & 1,2-Benzenedicarboxylic acid, bis(2-methylpropyl) ester & $\mathrm{C}_{16} \mathrm{H}_{22} \mathrm{O}_{4}$ & 278.35 & 0.01 \\
\hline 17.97 & Hexadecanoic acid, methyl ester & $\mathrm{C}_{17} \mathrm{H}_{34} \mathrm{O}_{2}$ & 270.45 & 0.00 \\
\hline 17.97 & Dodecanoic acid, 10-methyl-, methyl ester & $\mathrm{C}_{14} \mathrm{H}_{28} \mathrm{O}_{2}$ & 228.37 & 0.00 \\
\hline 18.43 & Dibutyl phthalate & $\mathrm{C}_{16} \mathrm{H}_{22} \mathrm{O}_{4}$ & 278.34 & 0.00 \\
\hline 18.43 & Phthalic acid, butyl hex-3-yl ester & $\mathrm{C}_{19} \mathrm{H}_{28} \mathrm{O}_{4}$ & 320.42 & 0.00 \\
\hline 19.69 & $9,12,15$-Octadecatrienoic acid & $\mathrm{C}_{18} \mathrm{H}_{30} \mathrm{O}_{2}$ & 278.43 & 0.01 \\
\hline 19.69 & $2,4,6,8,10$-Tetradecapentaenoic acid & $\mathrm{C}_{36} \mathrm{H}_{46} \mathrm{O}_{8}$ & 606.74 & 0.01 \\
\hline 23.47 & 1-Monolinoleoylglycerol trimethylsilyl ether & $\mathrm{C}_{27} \mathrm{H}_{54} \mathrm{O}_{4} \mathrm{Si}_{2}$ & 498.88 & 0.00 \\
\hline 23.47 & Octasiloxane & $\mathrm{C}_{16} \mathrm{H}_{48} \mathrm{O}_{7} \mathrm{Si}_{8}$ & 577.23 & 0.00 \\
\hline 26.32 & Propanoic acid & $\mathrm{C}_{27} \mathrm{H}_{42} \mathrm{O}_{4}$ & 430.62 & 0.03 \\
\hline 26.32 & 1H2-,8a-Methanocyclopenta [a]cyclopropa[e]cyclodecen-11-one & $\mathrm{C}_{26} \mathrm{H}_{34} \mathrm{O}_{8}$ & 474.54 & 0.03 \\
\hline 27.87 & Butanoic acid & $\mathrm{C}_{24} \mathrm{H}_{32} \mathrm{O}_{6}$ & 416.50 & 0.03 \\
\hline 28.20 & Morphinan & $\mathrm{C}_{22} \mathrm{H}_{33} \mathrm{NO}_{3} \mathrm{Si}_{2}$ & 415.67 & 0.00 \\
\hline 28.20 & Milbemycin b & $\mathrm{C}_{33} \mathrm{H}_{46} \mathrm{C}_{1} \mathrm{NO}_{7}$ & 604.17 & 0.00 \\
\hline 29.17 & 9-Desoxo-9-x-acetoxy-3,8,12-tri-O-acetylingol & $\mathrm{C}_{28} \mathrm{H}_{40} \mathrm{O}_{10}$ & 536.61 & 0.00 \\
\hline 29.17 & 1-HCyclopropa[3,4]benz[1,2-e] azulene5,7b,9,9a-tetrol & $\mathrm{C}_{26} \mathrm{H}_{36} \mathrm{O}_{8}$ & 476.55 & 0.00 \\
\hline 29.30 & .psi...psi.-Carotene & $\mathrm{C}_{42} \mathrm{H}_{64} \mathrm{O}_{2}$ & 600.95 & 0.00 \\
\hline 29.30 & Lycophyll & $\mathrm{C}_{40} \mathrm{H}_{56} \mathrm{O}_{2}$ & 568.87 & 0.00 \\
\hline 29.48 & Stigmast-5-en-3-ol,oleate & $\mathrm{C}_{47} \mathrm{H}_{82} \mathrm{O}_{2}$ & 679.15 & 0.01 \\
\hline 29.48 & Stigmastan-3-ol,5-chloro-,acetate & $\mathrm{C}_{31} \mathrm{H}_{53} \mathrm{C}_{1} \mathrm{O}_{2}$ & 493.20 & 0.01 \\
\hline 33.10 & Methanesulfonic acid & $\mathrm{CH}_{4} \mathrm{O}_{3} \mathrm{~S}$ & 96.10 & 0.00 \\
\hline 33.92 & Ç-Sitosterol & $\mathrm{C}_{29} \mathrm{H}_{50} \mathrm{O}$ & 414.70 & 0.01 \\
\hline 35.87 & Demecolcine & $\mathrm{C}_{21} \mathrm{H}_{25} \mathrm{NO}_{5}$ & 371.42 & 0.00 \\
\hline 35.87 & Oleic acid, 3-(octadecyloxy)propyl ester & $\mathrm{C}_{39} \mathrm{H}_{76} \mathrm{O}_{3}$ & 593.01 & 0.00 \\
\hline
\end{tabular}

stable compound with a yellow color by reacting with an antioxidant, and the extent of the reaction depends on the hydrogen donating ability of the antioxidant. ${ }^{47-49}$ The scavenging ability of $M$. sericea on DPPH is shown in Figure 6 and compared with that of ascorbic acid. The scavenging effect of extract and standard on the DPPH radical was expressed as percentage inhibition. Figure 6, shows the results of $M$. sericea at various concentrations in comparison with same doses of ascorbic acid and showed dose-dependent DPPH radicals scavenging activity. The scav- enging activity of the investigated extract varied widely from 5.53 to $82.15 \%$ (observed $\mathrm{IC}_{50}$ value $79.83 \mu \mathrm{g} / \mathrm{ml}$ ) and in standard from 17.29 to $\% 88.82\left(\mathrm{IC}_{50}\right.$ value $\left.36.23 \mu \mathrm{g} / \mathrm{ml}\right)$.

The ABTS test is also commonly employed to study antioxidant screening in plants based on the potential of the extracts to scavenge the radical cation $\mathrm{ABTS}^{*+}$ generated during the application of this method. ${ }^{50,51}$ In ABTS scavenging method, the extract showed dose dependent free 
radical scavenging activity as shown in Figure 7. Extract exhibited potent scavenging activity against ABTS with an $\mathrm{IC}_{50}$ value of $25.406 \mu \mathrm{g} / \mathrm{mL}$ almost equivalent to that of standard ascorbic acid $\left(\mathrm{IC}_{50}\right.$ value $13.260 \mu \mathrm{g} /$ $\mathrm{mL}$ ). The percent inhibition was $90.9 \%$ and $87.6 \%$ for the leaf extract and ascorbic acid respectively at $100 \mu \mathrm{g} / \mathrm{mL}$ concentration.

It is well known that nitric oxide is an important chemical mediator generated by endothelial cells, macrophages and neurons. Excess production of nitric oxide may cause several diseases..$^{52}$ Therefore, it is reported that the phytochemicals such as flavonoids and phenolics present in this plant might play an important role in scavenging of nitric oxide radicals generated. ${ }^{53}$ The present study revealed that the extract showed greater scavenging activity with reference to standard ascorbic acid with $\mathrm{IC}_{50}$ values of extract and standard were $6.352 \mu \mathrm{g} / \mathrm{ml}$ and $1.477 \mu \mathrm{g} / \mathrm{ml}$ respectively (Figure 8).

In the reducing power assay, the presence of antioxidants in the samples would result in the reducing of $\mathrm{Fe}^{3+}$ to $\mathrm{Fe}^{2+}$ by donating an electron. Amount of $\mathrm{Fe}^{2+}$ complex can be then be monitored by measuring the formation of Perl's Prussian blue at $700 \mathrm{~nm}$. The extract showed promising reducing power ability, which reflected its antioxidant potential and increased with increase in concentration. Fe (III) reduction is often used as an indicator of electron donating activity, which is an important mechanism of phenolic antioxidant action. ${ }^{54}$ The $\mathrm{OD}$ at $700 \mathrm{~nm}$ increased in a dose dependent manner from 0.080 at $100 \mu \mathrm{g} / \mathrm{ml}$ to 0.708 at $750 \mu \mathrm{g} / \mathrm{ml}$. For this assay also, BHA and quercetin were used as a standard. The OD at $700 \mathrm{~nm}$ ranged from 0.100 at $5 \mu \mathrm{g} / \mathrm{ml}$ to 0.435 at $40 \mu \mathrm{g} / \mathrm{ml}$ and 0.104 at $5 \mu \mathrm{g} / \mathrm{ml}$ to 1.618 at $40 \mu \mathrm{g} / \mathrm{ml}$. The extract showed stronger reducing power, but not stronger than the reference standard.

The FRAP method is often used to ascertain the antioxidant activity of plant materials by measuring the capacity of the extracts to reduce ferric complexes to the ferrous form..$^{55}$ The estimated FRAP value for the leaves extract was $36.75 \mu \mathrm{g} / \mathrm{mg}$ of the extract with equivalent to ascorbic acid ( $\mathrm{Y}=0.020 \mathrm{x}-0.044 \mathrm{R}^{2} 0.987$ )

The total antioxidant capacity using phosphomolybdenum method assay is based on the reduction of Mo (VI) to Mo (V) by the sample analyte and the subsequent formation of green phosphate/Mo (V) complex at acidic $\mathrm{pH} .{ }^{56}$ The phosphomolybdenum method is quantitative since the total antioxidant activity is expressed as the number of equivalents of ascorbic acid. Total antioxidant capacity of the extract was $248.26 \%$.

\section{CONCLUSION}

In this study, in-vitro antioxidant activities and chemical composition (FTIR, GC-MS and HPLC) of aqueous-methanolic extract obtained from the leaves of $M$. sericea was assessed. Moreover, it was reported for the first time, the antioxidant capacity of this plant along with the characterization of the biomolecules of the leaves extract. In all tested methods, the antioxidant activity of aqueous-methanolic leaves extract was compared with that of ascorbic acid, which is a well-known potent antioxidant. The extract showed good antioxidant capacity in almost all the antioxidant assays tested when compared with reference standard. The activity was due to the phenolics present in the extract and are confirmed by the presence of some potent phenolic compounds like rutin, cinnamic acid and salicylic acid through GC-MS and RP-HPLC analysis. Based on this work it can be concluded that this plant can be a good source of natural antioxidant for food, and nutraceutical preparations. Further, in vivo study, involving animal models, and more advanced studies should be conducted to isolate the active principles to establish the molecular mechanism of action of the molecule that will provide a better insight into the antioxidative potential of the studied plant species.

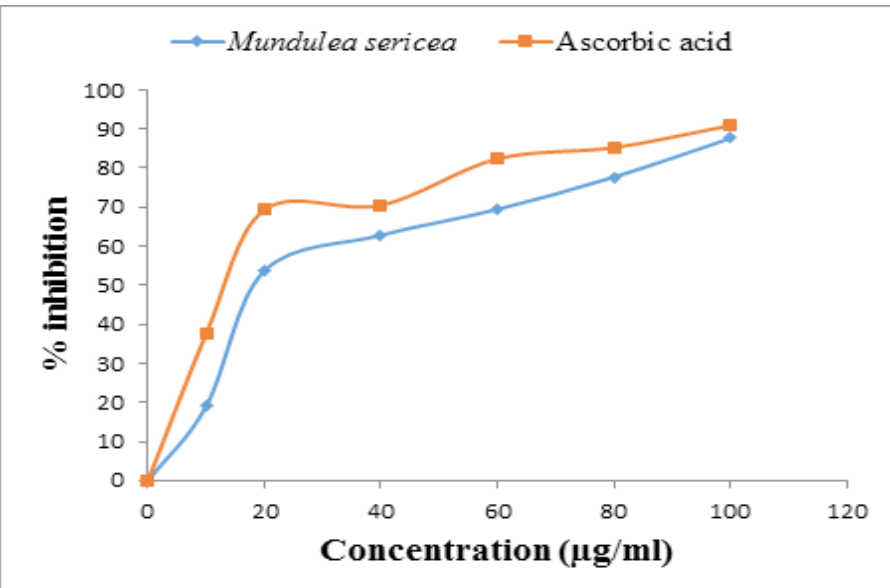

Figure 7: ABTS scavenging activity of aqueous-methanolic leaves extract of M. sericea

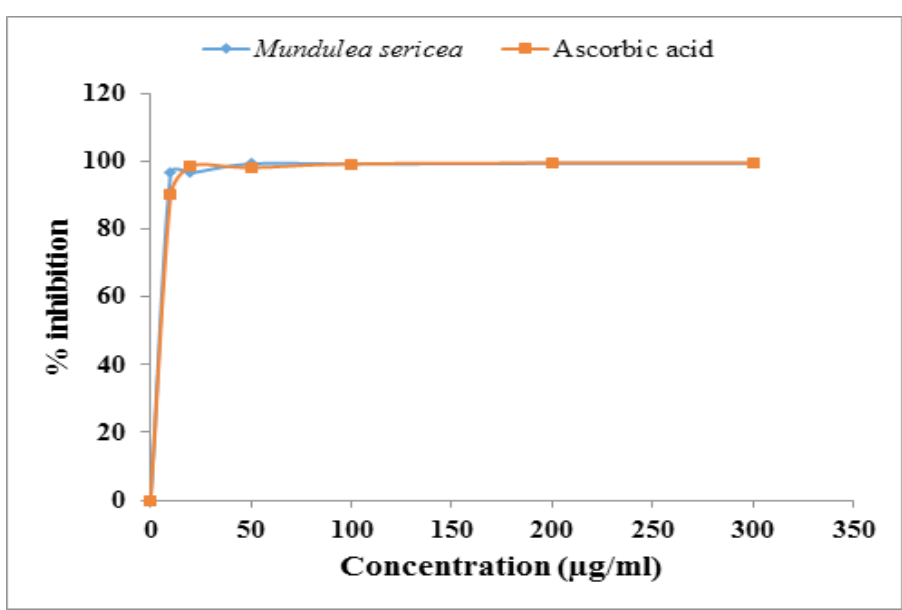

Figure 8: Nitric oxide scavenging activity of aqueous-methanolic leaves extract of M. sericea

\section{ACKNOWLEDGEMENT}

Authors are thankful to SAIF, Punjab University, Chandigarh for GCMC characterization. The first author expresses sincere thanks to Principal, S.N. Arts, D.J.M. Commerce and B.N.S. Science College, Sangamner for providing necessary facilities.

\section{CONFLICT OF INTEREST}

The authors declare that there is no conflict of interest.

\section{ABBREVIATION USED}

DPPH: 2,2 diphenyl-1-picrylhydrazyl; ABTS: 2, 2-Azino-bis (3-ethylbenzthiazoline-6-sulphonic acid) radical-scavenging assay; FRAP: Ferric reducing antioxidant power; TPC: Total phenolic content; TFC: Total flavonoid content; PBS: Phosphate buffer saline; TCA: Trichloroacetic acid; TPTZ: Tripyridil-s-triazine; IC $_{50}$ : Inhibitory concentration 50\%; M: Molar; mM: Millimolar; ml: millilitre; $\mathbf{n m : ~ n a n o m e t e r ; ~} \boldsymbol{\mu g}$ : microgram; mg: milligram; FT-IR: Fourier Transform infra red spectrometry; GC-MS: Gas Chromatography-Mass Spectrometry; HPLC: High performance liquid chromatography.

\section{REFERENCES}

1. Kong KW, Mat J.S, Aminudin N, Ismail A, Abdul A.A. Antioxidant activities and polyphenolics from the shoots of Barringtonia racemosa (L.) Spreng in a po- 
lar to a polar medium system. Food Chem. 2012;134(1):324-32. http://dx.doi. org/10.1016/j.foodchem.2012.02.150

2. Georgieva E, Karamalakova Y, Nikolova G, Grigorov B, Pavlov D, Gadjeva V, et al. Radical scavenging capacity of seeds and leaves ethanol extracts of $\mathrm{Cy}$ nara scolymus L.-A comparative study. Biotechnology Biotechnol Equip. 2012;26(1):151-5. http://dx.doi.org/10.5504/50YRTIMB.2011.0028.

3. Lawrence BM. Commercial production of non-citrus essential oils in North America. Perfumer Flavorist. 1979;3(6):21-33.

4. Zupko J, Hohmann D, Redei G, Falkay G, Janicsa K, Mathe I. Antioxidant activity of leaves of salvia species in enzyme-dependent and enzyme-independent systems of lipid peroxidation and their phenolic constituents. Planta Med. 2001;67(4):366-8. http://dx.doi.org/10.1055/s-2001-14327 PMid:11458459.

5. Miliauskas G, Venskutonis PR, Van Beek TA. 2004. Screening of radical scavenging activity of some medicinal and aromatic plant extracts. Food Chem. 2004;85(2):231-7. http://dx.doi.org/10.1016/j.foodchem.2003.05.007.

6. Anonymous, 1985. The Wealth of India (Raw Materials). Publications and information Directorate, Council of Scientific and Industrial Research, New Delhi. 1962;6:444-5.

7. Iyer M, Karode R, Deshmukh R, Deshmukh V. Anti-nociceptive activity of Mundulea sericea leaves. J Nat Rem. 2004;4(2):127-30.

8. Luyengi L, Lee I, Mar W, Harry HS, Pezzuto JM, Douglas A. Rotenoids and chalcones from Mundulea sericea that inhibit phorbol ester-induced ornithine decarboxylase activity. J Phytochemicals. 1994;36(6):1523-6. http://dx.doi. org/10.1016/S0031-9422(00)89755-1.

9. Magaji BT, Bamaiyi LJ, Igheghe L, Mani U. Bioassay of Mundulea sericea ethanol leaf extract and leaf powder against Callosobruchus maculatus F. on stored cowpea. Global J Sci Fronti Res Agri Vet Sci. 2012;12(9):31-6.

10. Langat BK, Siele DK, Wainaina C, Mwandawiro C, Ondicho J, Tonui WK, et al. Larvicidal effect of Mundulea sericea (Leguminosaea) plant extract against Aedes aegypti L. (Diptera: Culicidae). African J Pharmacol Therap. 2012;1 (3):106-9.

11. Anjili CO, Mugambi R, Siele DK, Langat B, Kamanyi K, Nyasende S, et al. The effects of Mundulea sericea (Fabales: Fabaceae) water extracts on Phlebotomus duboscqi (Diptera: Psychodidae) eggs and larvae. African J Pharmacol Therap. 2014;3(2):47-50.

12. Chopra RN, Nayer SL, Chopra IC. Glossary of Indian Medicinal Plants. New Delhi: Council of Scientific and Industrial Research; 1956.

13. Mazimbaa O, Masesanea IB, Majindaa RRT, Muzila A. GC-MS analysis and antimicrobial activities of the non-polar extracts of Mundulea sericea. South Afr $J$ Chem. 2012;65:50-2.

14. Cooke T. 1903. Flora of Presidency of Bombay, vol.1. London: Published under the Authority secretary of State for Council; 1903.

15. Pradhan SG, Singh NP. Flora of Ahmednagar District (M.S.). Dehradun: Bishen Singh Mahendra Pal Singh. 1999;45-6. Title Missing??

16. Harborne JB. Phytochemical methods. London: Chapman Hall, 1984. http:// dx.doi.org/10.1007/978-94-009-5570-7 PMCid:PMC1193218.

17. Mahida Y, Mohan JSS. Screening of Indian plant extracts for antibacterial activity. Pharma Biol. 2006;44(8):627-31. http://dx.doi.org/10.1080/13880200600897551.

18. Cliffe S, Fawer M, Maier G. Takata K, Ritter G. Enzyme assays for the phenolic content of natural juices. J Agri Food Chem. 1994;42(8):1824-8. http://dx.doi. org/10.1021/jf00044a048.

19. Kasote DM, Bhalerao BM, Jagtap SD, Khyade MS, Deshmukh KK. Antioxidant and alpha-amylase inhibitory activity of methanol extract of Colocasia esculenta Corm. Pharmacologyonline. 2011;2:715-21.

20. Zou Y, LuY, Wei D. Antioxidant activity of a flavonoid-rich extract of Hypericum perforatum L. in vitro. J Agri Food Chem. 2004;52(16):5032-9. http://dx.doi. org/10.1021/jf049571r PMid:15291471.

21. Yen GC, Chen HY. Antioxidant activity of various tea extracts in relation to their anti-mutagenicity. J Agri Food Chem. 1995;43(1):27-32. http://dx.doi. org/10.1021/jf00049a007.

22. Re R, Pellegrini N, Proteggente A, Pannala A, Yang M, Rice-Evans C. Antioxidant activity applying an improved ABTS radical cation decolorization assay. Free Radic Biol Med. 1999;26(9-10):1231-7. http://dx.doi.org/10.1016/S08915849(98)00315-3.

23. Ilavarasan $\mathrm{R}$, Mallika M, Venkataraman S. Anti-inflammatory and antioxidant activites of Cassia fistula Linn bark extract. Afr J Tradit. 2005;1:70-85.

24. Benzie IF, Strain JJ. Ferric reducing/antioxidant power assay: Direct measure of total antioxidant activity of biological fluids and modified version for simultaneous measurement of total antioxidant power and ascorbic acid concentration. Methods Enzymol. 1999;299:15-27. http://dx.doi.org/10.1016/S00766879(99)99005-5.

25. Prieto $\mathrm{P}$, Pineda M, Aguilar M. Spectrophotometric quantitation of antioxidant capacity through the formation of a phosphomolybdenum complex: Specific application to the determination of vitamin E. Anal Biochem. 1999;269(2):337-41. http://dx.doi.org/10.1006/abio.1999.4019 PMid:10222007.

26. Shirwaikar A, Rajendran K, Kumar CD. In vitro antioxidant studies of Annona squamosa Linn. leaves. Indian J Exp Biol. 2004;42(8):803-7. PMid:15573531.

27. Janakiraman N, Sathish SS, Johnson M. UVVIS and FTIR Spectroscopic studies on Peristroph bicalyculata (Retz.) Nees. Asian J Pharm Clin Res. 2011;4(4):125-
28. Etuk EU, Agaie BM, Ladan MJ, Garba I. The modulatory effect of Cochlospermum tinctorium a rich aqueous root extract on liver damage induced by carbon tetrachloride in rats. Afr J Pharm Pharmacol. 2009;3(4):151-7.

29. Sahreen S, Khan MR, Khan RA. Evaluation of antioxidant activities of various solvent extracts of Carissa opaca fruits. Food Chem. 2010;122(4):1205-11. http:// dx.doi.org/10.1016/j.foodchem.2010.03.120.

30. Motar MLR, Thomas G, Barbosa Fillo JM. Effects of Anacardium occidentale stem bark extract on in vivo inflammatory models. J Ethnopharmacol. 1985;95(2):139-42.

31. Ruch RJ, Cheng SJ, Klaunig JE. Prevention of cytotoxicity and inhibition of intercellular communication by antioxidant catechins isolated from Chinese green tea. Carcinogen. 1989;10(6):1003-8. http://dx.doi.org/10.1093/carcin/10.6.1003.

32. Ogunleye DS, Ibitoye SF. Studies of antimicrobial activity and chemical constituents of Ximenia americana. Trop J Pharm Res. 2003;2(2):239-41.

33. Thuong PT, Hung TM, Ngoc TM, Hado T, Min BS, Kwack SJ, et al. Antioxidant activities of coumarins from Korean medicinal plants and their structure-activity relationships. Phytother Res. 2010;24(1):101-6. http://dx.doi.org/10.1002/ ptr.2890 PMid:19468986.

34. Cheeke PP. Surprising benefits of desert plants. In The Linus Paulin Institute. Aregon University; 2005 volme issue and page nos missing??

35. Rice-Evans CA, Miller NJ, Bollwell PG, Bramley PM, Pridham JB. The relative antioxidant activities of plant-derived polyphenolic flavonoids. Free Radical Res. 1995;22(4):375-83. http://dx.doi.org/10.3109/10715769509145649.

36. Pietta DG. Flavonoids as antioxidants. J Nat Prod. 2000;63:1035-42. http:// dx.doi.org/10.1021/np9904509 PMid:10924197.

37. Khoudja NK, Makhlouf LB, Madani K. Antioxidant capacity of crude extracts and their solvent fractions of selected Algerian Lamiaceae. Ind Crops Prod. 2014;52:177-82. http://dx.doi.org/10.1016/j.indcrop.2013.10.004.

38. Poojari MM, Vishnumurthy KA, Adhikari AV. Extraction, characterization and biological studies of phytochemicals from Mammea suriga. J Pharmaceut Anal. 2013;5(3):182-9. http://dx.doi.org/10.1016/j.jpha.2015.01.002.

39. Yokozawa T, Chen CP, Dong E, Tanaka T, Nonaka Gl, Nishioka I. Study on the inhibitory effect of tannins and flavonoids against the 1,1-diphenyl-2 picrylhydrazyl radical. Biochem Pharmacol. 1998;56(2):213-22. http://dx.doi.org/10.1016/ S0006-2952(98)00128-2.

40. Kähkönen MP, Hopia Al, Vuorela HJ, Rauha HJ, Pihlaja K, Kujala TS, et al. Antioxidant activity of plant extracts containing phenolic compounds. J Agric Food Chem. 1999;7:3954-62. http://dx.doi.org/10.1021/jf990146l.

41. Liu F, Ng TB. Antioxidative and free radical scavenging activities of selected medicinal herbs. Life Sci. 2000;66(8):725-35 http://dx.doi.org/10.1016/S00243205(99)00643-8.

42. Diaz P, Jeong SC, Lee S, Khoo C, Koyyalamudi SR. Antioxidant and antiinflammatory activities of selected medicinal plants and fungi containing phenolic and flavonoid compounds. Chin Med. 2012:7(1):1-9. http://dx.doi. org/10.1186/1749-8546-7-26. PMid:23176585 PMCid:PMC3577437.

43. Silverio FO, Barbosa LCA, Silverstre AJD, Pilo-Veloso D, Gomide JL. Comparative study on the chemical composition of lipophilic fractions from three wood tissues of Eucalyptus species by gas chromatography-mass spectrometry analysis. J Wood Sci. 2007;53(6):533-40. http://dx.doi.org/10.1007/s10086-0070901-0.

44. Arunkumar S, Muthuselvam M. Analysis of phytochemical constituents and antimicrobial activities of Aloe vera L. against clinical pathogens. World J Agric Sci. 2009;5(5):572-76

45. Kaushik P, Lal S, Rana AC, Kaushik D. GC-MS analysis of bioactive constituents of Pinus roxburghii Sarg. (Pinaceae) from northern India. Res J Phytochem. 2014;8(2):42-6. http://dx.doi.org/10.3923/rjphyto.2014.42.46.

46. Prabhakar KR, Veeresh VP, Vipan K, Sudheer M, Priyadarsini KI, Satish RBSS Bioactivity-guided fractionation of Coronopus didymus: A free radical scavenging perspective. Phytomedicine. 2006;13(8):591-5. http://dx.doi.org/10.1016/i. phymed.2005.07.003 PMid:16920515.

47. Bondent $\mathrm{V}$, Brand-Williams $\mathrm{W}$, Bereset $\mathrm{C}$. Kinetics and mechanism of antioxidant activity using the DPPH. free radical methods. Lebensmittel Wissenschaf und Technologie. 1997;30(6):609-15. http://dx.doi.org/10.1006/fstl.1997.0240.

48. Lee JY, Hwang WK, Lim ST. Antioxidant and anticancer activities of organic extracts from Platycodon grandiflorum A. De Candolle roots. J Ethnopharmacol. 2004;93(2):409-15. http://dx.doi.org/10.1016/j.jep.2004.04.017 PMid:15234786.

49. Xi W, Zhang Y, Sun Y, Shen Yan, Ye X, Zhou Z. Phenolic composition of Chinese wild mandarin (Citrus reticulata Balnco.) pulps and their antioxidant properties. Ind Crops Prod. 2014;52:466-74. http://dx.doi.org/10.1016/j.indcrop.2013.11.016.

50. Gouveia S, Gonc AJ, Castilho PC. Characterization of phenolic compounds and antioxidant activity of ethanolic extracts from flowers of Andryala glandulosa ssp. varia (Lowe ex DC.) R.Fern. an endemic species of Macaronesia region. Ind Crops Prod. 2013;42:573-82. http://dx.doi.org/10.1016/j.indcrop.2012.06.040.

51. Kim DO, Lee KW, Lee HJ, Lee CY. Vitamin C equivalent antioxidant capacity (VCEAC) of phenolic phytochemicals. J Agric Food Chem. 2002;50(13):3713-7. http://dx.doi.org/10.1021/jf020071c PMid:12059148.

52. Ialenti A, Moncada S, Di Rosa M. Modulation of adjuvant arthritis by endogenous nitric oxide. $\mathrm{Br} \mathrm{J}$ Pharmacol. 1993;110(2):701-6. http://dx.doi. 
org/10.1111/j.1476-5381.1993.tb13868.x PMid:8242242 PMCid:PMC2175935.

53. Krishnamoorthy K, Krishnaswamy T, Subramaniam P, Sellamuthu M. Quantification of phytochemicals and in vitro antioxidant potential of various solvent extracts of certain species of Acanthaceae. Int J Green Pharm. 2014;8(1):58-64. http://dx.doi.org/10.4103/0973-8258.126826.

54. Nabavi SM, Ebrahimzadeh MA, Nabavi SF, Hamidinia A, Bekhradnia AR. Determination of antioxidant activity, phenol and flavonoids content of Parrotia persica Mey. Pharmacol Online. 2008;2:560 7.
55. Contreras-Calderón J, Calderón-Jaimes L, Guerra-Hernández E, García-Villanova B. Antioxidant capacity, phenolic content and vitamin $C$ in pulp, peel and seed from 24 exotic fruits from Colombia. Food Res Int. 2011;44(7):2047-53. http:// dx.doi.org/10.1016/j.foodres.2010.11.003.

56. Bhatti M, Kamboj A, Saluja1 A, Jain UK. In vitro evaluation and comparison of antioxidant activities of various extracts of leaves and stems of Kalanchoe pinnatum. Int J Green Pharm. 2012;6(4):340-7.http://dx.doi.org/10.4103/09738258.108255

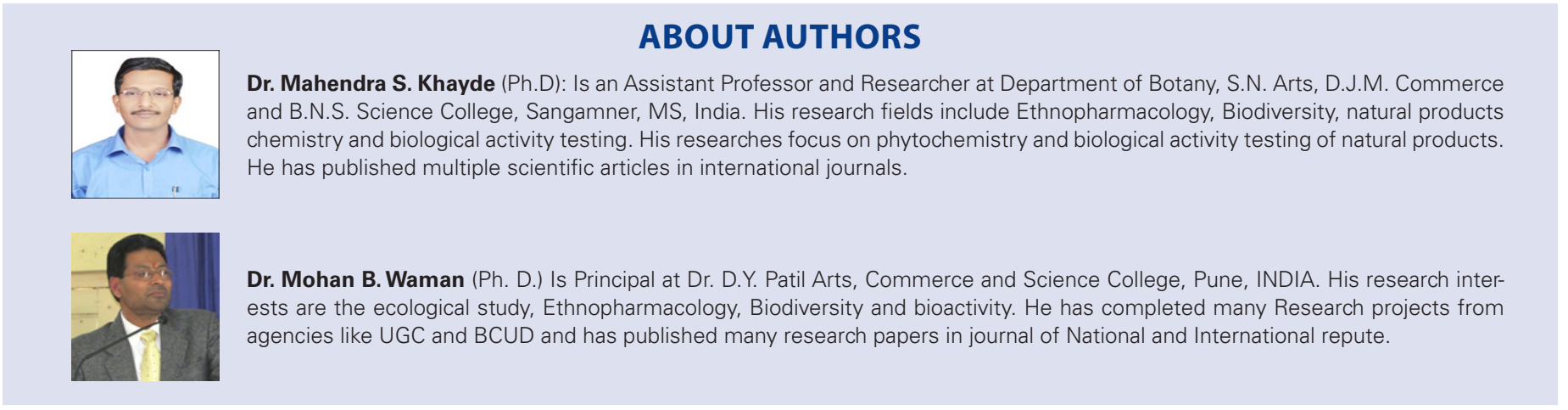

Cite this Article: Khyade MS,Waman MB. Chemical Profile and Antioxidant Properties of Mundulea sericea. Pharmacogn J. 2017;9(2):213-20. 